\title{
CONFIRMED OCCURRENCE OF THE NATIVE PLANT SPECIES ELEOCHARIS OVATA (CYPERACEAE) IN LITHUANIA
}

\author{
Zigmantas GUDŽINSKAS*, Laurynas TAURA
}

Nature Research Centre, Institute of Botany, Žaliųų Ežerų Str. 49, 12200 Vilnius, Lithuania

*Corresponding author. E-mail: zigmantas.gudzinskas@gamtc.lt

\begin{abstract}
Gudžinskas Z., Taura L., 2021: Confirmed occurrence of the native plant species Eleocharis ovata (Cyperaceae) in Lithuania. - Botanica, 27(1): 44-52.

Information on the occurrence of Eleocharis ovata (Cyperaceae) in Lithuania for a long time had been based on misidentified specimens only. During the studies on the flora of South Lithuania in 2020, we discovered this species in Varéna district on the shores of Lake Pabezninkai. We performed field investigations on the distribution, size of population and habitats of E. ovata from August to October 2020 on the shores of Lake Pabezninkai and, searching for this species, surveyed potential habitats on the shores of eight other lakes in South Lithuania. A total of 63 individuals of $E$. ovata were found on the shores of Lake Pabezninkai, and they were widely dispersed on the northern and south-western shores of the lake. Most of the registered individuals of $E$. ovata were found growing on wet sand and mud in the communities of the Isoëto-Nanojuncetea class. Solitary individuals were also found in communities of the Phragmito-Magnocaricetea class. Assessment of E. ovata according to the IUCN criteria revealed that this species, currently occurring at a single locality in Lithuania, should be classified as critically endangered (CR). Conservation of E. ovata and other rare plant species recorded on the shores of Lake Pabezninkai should be organised by maintaining favourable habitat conditions.
\end{abstract}

Keywords: conservation, distribution, habitats, population size, reproduction.

\section{INTRODUCTION}

The diversity of flora in a particular geographic area is determined by climatic, geological, soil, orographic conditions and depends on the intensity of historical and current human activities (LINDER, 2005; Di MARco \& SANTINI, 2015). Although studies on the flora, as an assemblage of plant taxa in a specific geographic area, have received less attention worldwide in recent decades, they are an essential part of knowledge about biodiversity. Furthermore, the studies on the flora provide answers to questions on plant evolution and phytogeography (Funk, 2006). Understanding the genesis of plant diversity is also vital for the long-term planning of biodiversity conservation (DI Marco \& SANTINI, 2015).

The Cyperaceae family comprises one of the largest families of vascular plants, including ca. 5400 species in 106 genera (GOVAERTS et al., 2007). In Lithuania, the Cyperaceae family is the third-largest plant family, and its diversity has been relatively well-studied (LekaviČIUS, 1963; StanceviČIUS, 1963; KuUsk et al., 2003). Nevertheless, several earlier not registered taxa of this family have been recorded during the last decades: Carex depressa Link subsp. transsilvanica (Schur) T.V. Egorova, C. filiformis L. [= C. tomentosa L.], C. juncella (Fr.) Th.Fr. [= C. nigra (L.) Reichard subsp. juncea (Fr.) Soó] (Matulevičıūtė, 2001, 2003), Scirpus radicans Schkuhr (GudžInSKAS \& TAura, 2021). Our studies on the flora of South Lithuania in 2020 led to the discovery of Eleocharis ovata (Roth) Roem. et Schult., a species that had been reported in the country based only on misidentified specimens (GUDŽINSKAS, 1999; TABAKA et al., 2003).

The genus Eleocharis R. Br. includes about 200 
species distributed mainly in the Northern hemisphere and occupying various types of wetland and marsh habitats (GonzÁLez-Elizondo \& Peterson, 1997). In Lithuania, depending on the accepted taxonomical concepts, this genus has been reported including eight (LeKAVIČIUS, 1963), seven (GUDŽINSKAs, 1999) or five (TABAKA et al., 2003) species. Considering the currently accepted taxonomical point of view (GovAERTS et al., 2007), now this genus is represented in Lithuania by six species: E. acicularis (L.) Roem. et Schult., E. mamillata (H.Lindb.) H.Lindb., E. ovata (Roth) Roem. et Schult., E. palustris (L.) R.Br., E. quinqueflora (Hartmann) O. Schwarz and E. uniglumis (Link) Schult.

Although E. ovata is considered a species with an almost circumboreal range, it is distributed unevenly, and in some regions, it is absent (GALEN SMITH et al., 2002; JimÉneZ-MeJías \& LuCEÑo, 2011; Simons et al., 2020). In Europe, it is also distributed unevenly and in many regions is considered as rare and threatened species (ZająC \& ZająC, 2001; KirÁly et al., 2008; Verloove, 2015; Simons et al., 2020). In the Baltic region, E. ovata is extremely rare, and its populations usually are temporal. In Estonia, for example, E. ova$t a$ was registered at the end of the 19th century, and one new record was made in the south-eastern part of the country in 2012 (KUUK, 1999, 2020; TABAKA et al., 2003). The occurrence of this species in Latvia was recorded only in the 19th century and later was not found (TABAKA et al., 2003; Priedītis, 2014). In former East Prussia, this species was found growing on the shores of ponds or in drained ponds in the second half of the 19th century, and the last record was made in 1894 (AвROMEIT et al., 1940). In the nowadays Kaliningrad Region of Russia, E. ovata has been recognised as extinct species (DEDKov et al., 2010). Although this species has been recorded almost throughout Belarus, it is considered a rare native species in the southern part of the territory and casual alien in the northern part of the country (SKURATOVICH, 2017). In Poland's north and central part, this species is also rare and somewhat more frequent in the south (ZAJĄC \& ZAJĄC, 2001).

In Lithuania, E. ovata formerly has been reported to occur in various parts of the country (SŁAWIŃSKI, 1924; Snarskis, 1954; LekaviČIUS, 1963). However, later revision of the herbarium specimens has shown that all reports were based on misidentified speci- mens (TABAKA et al., 2003). Thus, this species has not been confirmed in Lithuania; however, considering its native range, it has been anticipated to occur in the country (GUDŽINSKAS, 1999). With the discovery of this species in Varena district, we aimed to evaluate the size of its population, distribution patterns on the shores of Lake Pabezninkai, to analyse threats and estimate the need for conservation.

\section{MATERIALS AND METHODS}

We performed field investigations on the distribution, size of population and habitats of E. ovata on the shores of Lake Pabezninkai in Varena district (South Lithuania) from August to October 2020. Potential habitats of other lakes in South Lithuania (Didžiulis, Dusia, Glèbas, Glūkas, Kastinis, Lavysas, Netečius, Seirijis) were also investigated searching for Eleocharis ovata. Voucher specimens of E. ovata collected during this research were deposited at the Herbarium of the Institute of Botany of the Nature Research Centre, Vilnius (BILAS). Herbarium specimens collected in Lithuania and formerly identified as $E$. ovata were analysed, and their identification was verified. Historical information on E. ovata in Lithuania, published in the literature, was also screened and assessed.

A distribution map of E. ovata in Lithuania was compiled applying a system of grid cells, which were arranged according to geographical coordinates with sides of $6^{\prime}$ of latitude and $10^{\prime}$ of longitude. The distribution map of E. ovata on the shores of Lake Pabezninkai was compiled using recorded geographical coordinates in the field. The number of individuals was counted thoroughly surveying sandy and muddy shores of Lake Pabezninkai (ca. $4.2 \mathrm{~km}$ long and 30$100 \mathrm{~m}$ wide, occasionally wider).

\section{RESULTS}

Information on the occurrence of E. ovata in Lithuania had been for a long time controversial. SNARSKIS (1954) has indicated that this species is unevenly distributed in Lithuania, and it is even frequent locally. However, all herbarium specimens collected by P.Snarskis in North and South Lithuania in 1942-1951 and identified as E. ovata (labelled as Heleocharis ovata (Roth) Roem. et Schult. or Scir- 
pus ovatus Roth) belong to Eleocharis quinqueflora (Hartmann) O.Schwarz. Thus, based on the re-identification of specimens by $\mathrm{V}$. Rašomavičius in 1999, TABAKA et al. (2003) have concluded that his species in Lithuania is misreported.

Eleocharis ovata (Roth) Roem. et Schult. (Scirpus ovatus Roth) is an annual, $2-35 \mathrm{~cm}$ tall plant with densely tufted culms and without rhizomes or stolons (Fig. 1). Leaf sheath basally slightly red, apically greenish or yellowish, apex obtuse to acute. Spikelet ovoid to broadly ovoid, $4-8 \mathrm{~mm}$ long and 3-4 mm wide, dense, many-flowered, with acute apex, usually brown. Basal 2 glumes sterile. Fertile glumes greenish medially and dark red on sides, laxly imbricate, ovate, $1.5 \mathrm{~mm}$ long and $0.5 \mathrm{~mm}$ wide, membranous. Perianth bristles 6, retrorsely spinulose. Stigmas 2 . Nutlet brownish at maturity, obovoid, ca. $0.8 \mathrm{~mm}$ long and $0.5 \mathrm{~mm}$ wide, conspicuously convex on the dorsal side. Persistent style base (stylopodium) deltoid, about one third as long and two-thirds as wide as nutlet.

The first locality of E. ovata in Lithuania was found in Varèna district, $2 \mathrm{~km}$ southeast of Sarapiniškès Village, in the environs of Aukštakalnis settlement (Fig. 2), on the north-eastern shore of Lake Pabezninkai (27 August 2020; $54.35198^{\circ} \mathrm{N}, 24.57328^{\circ} \mathrm{E}$ ). Two solitary individuals growing in a wet, muddy sand ca. $140 \mathrm{~m}$ apart were found on the shore of the lake.

Later, in September and at the beginning of October 2020, we thoroughly surveyed all shores of Lake Pabezninkai, counting and registering found individuals of E. ovata. The survey results showed that most of the individuals were dispersed along the northern and south-western shores of the lake, and solitary individuals were found on the north-eastern shore (Fig. 3). On the northern shore of the lake, which was covered by wet coarse sand with pebbles, we registered 14 individuals of E. ovata. Individuals were quite widespread along $260 \mathrm{~m}$ long coastline, usually from 10 to $30 \mathrm{~m}$ apart and only in two cases individuals were separated by less than $10 \mathrm{~m}$ distance. The mean distance between individuals was $18.6 \mathrm{~m}$ along the northern shore. On the south-western shore of the lake, E. ovata was more abundant, and a total of 47 individuals were found growing mainly in wet mud or wet coarse sand along $750 \mathrm{~m}$ long coastline. Individuals of this species were also dispersed, and the mean distance between individuals was $16 \mathrm{~m}$, although in several cases, one to three individuals grew within one to three meters apart. It should be noted that we found no individuals of E. ovata on the southeastern and north-western shores. The south-eastern exposed shore was covered by fine sand and was almost dry in September 2020. The north-western exposed shore of the lake was covered by wet fine sandy mud. Thus, 63 individuals of E. ovata were found on the shores of Lake Pabezninkai in 2020. Plant communities with E. ovata occupied 1.91 ha; therefore, the mean density was 33.0 individuals per hectare. The length of the shoreline with plants of E. ovata was $1150 \mathrm{~m}$; thus, the mean distance between individuals was $18.2 \mathrm{~m}$.

Despite the search for E. ovata on exposed sandy and muddy shores of other lakes in South Lithuania
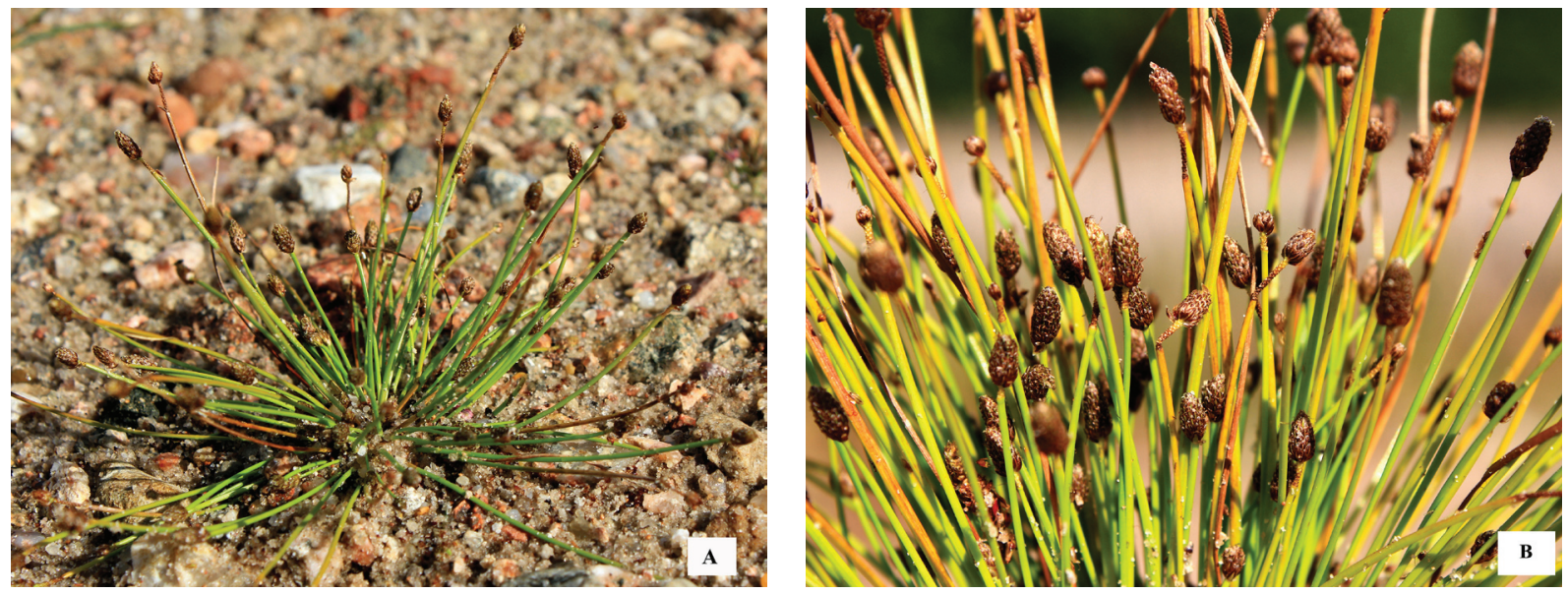

Fig. 1. General appearance (A) and close-up view (B) of Eleocharis ovata recorded on the shores of Lake Pabezninkai in 2020 


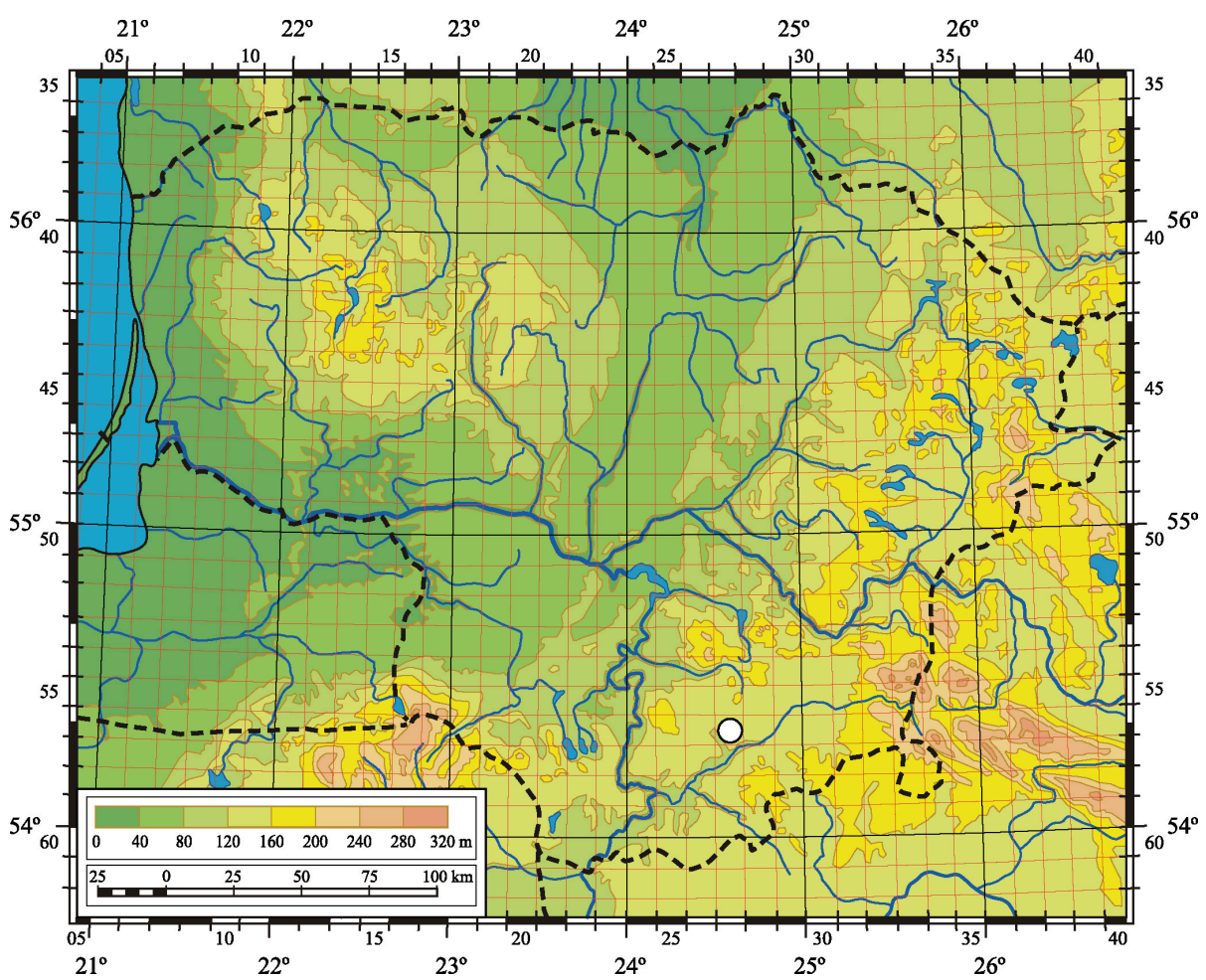

Fig. 2. Location of the recorded Eleocharis ovata population in Lithuania (white dot)

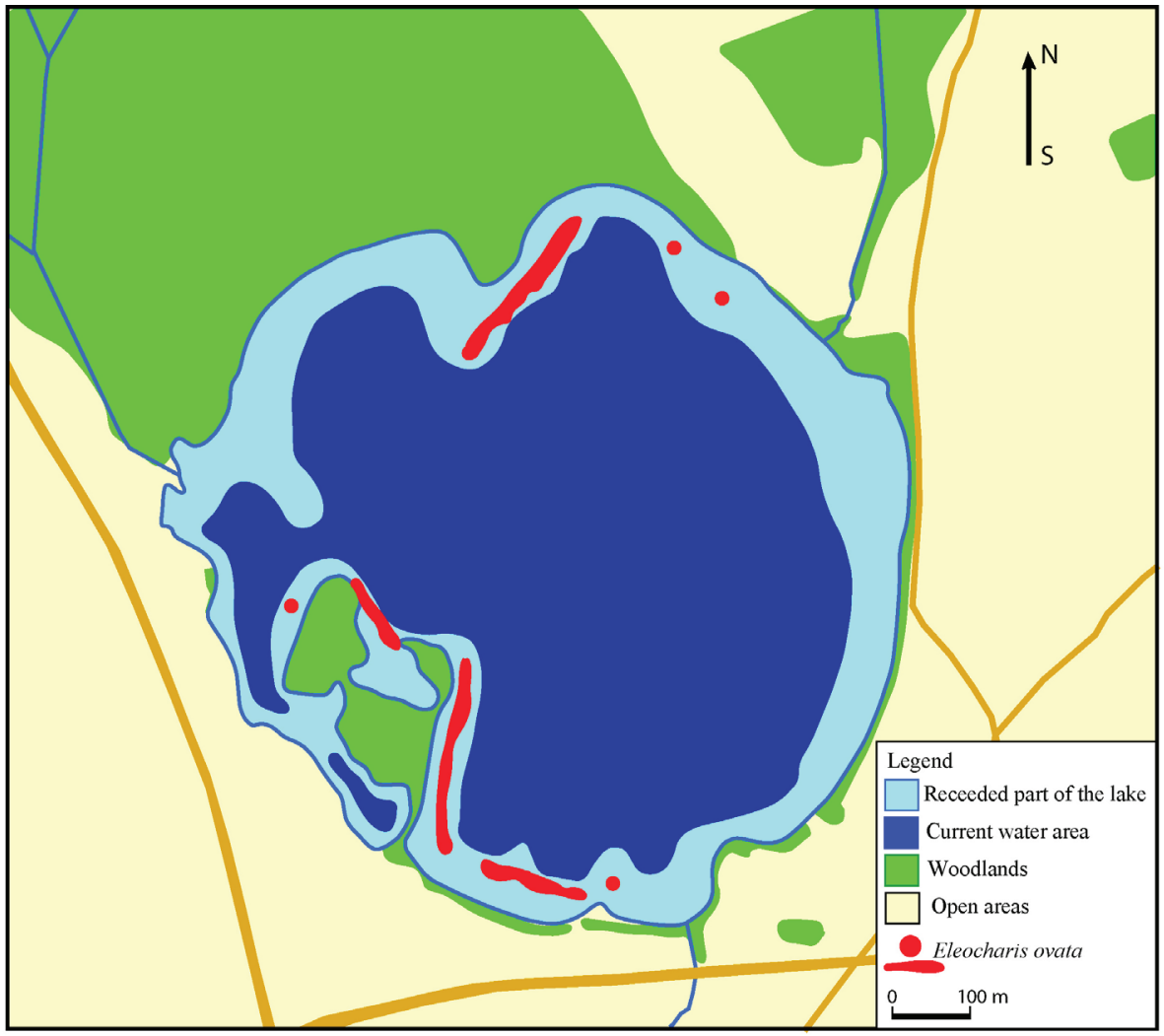

Fig. 3. Distribution of Eleocharis ovata on the shores of Lake Pabezninkai in 2020 
(Lakes Didžiulis, Dusia, Glèbas, Glūkas, Kastinis, Lavysas, Netečius, Seirijis), it was not recorded. Exposed wet muddy and sandy shores of Lakes Glëbas and Glūkas were particularly wide at the end of summer and in autumn of 2020, and suitable habitats occupied large areas; however, E. ovata was not found.

Individuals of $E$. ovata were found in quite a narrow belt of exposed banks of Lake Pabezninkai, usually in 5-20 m from the water. Most of the plants occurred in communities of the Isoëto-Nanojuncetea Br.-Bl. et Tüxen ex Br.-Bl. et al. 1952 class. The most frequent and abundant species were Juncus articulatus, J. bufonius, J. bulbosus and Gnaphalium uliginosum. Other species characteristic of wet sand or mud habitats, such as Limosella aquatica, Lythrum portula, Ranunculus reptans, were rare and usually represented by solitary individuals in the communities. Eleocharis ovata was also found in communities of the Scirpetum radicantis Nowiński 1930 association (class Phragmito-Magnocaricetea Klika in Klika et Novák 1941). Nevertheless, only solitary individuals were recorded in these communities; they were present in all study plots. Seven individuals of Eleocharis ovate were found growing in communities of the Phragmito-Magnocaricetea class and 56 individuals in communities of the Isoëto-Nanojuncetea class.

The results of our study revealed that E. ovata occurs in Lithuania in a single locality. Thus, the extent of occurrence and the area of occupancy of this species, in the sense of the IUCN (2017) criteria, are less than $10 \mathrm{~km}^{2}$. Furthermore, the number of recorded mature individuals in a single known locality was lower than the upper threshold (250 individuals) applied for critically endangered species (CR). A total of 63 individuals were recorded on the shores of Lake Pabezninkai in 2020. Considering the current state of habitats along the shores of Lake Pabezninkai and peculiarities of water level fluctuations in the lake, we infer the decline of E. ovata population in the future. Therefore, we estimate the state of $E$. ovata as critically endangered (CR) [B1ab(iii) + 2ab(iii); C2a(ii)] in Lithuania.

\section{DISCUSSION}

The records of $E$. ovata in Lithuania have been mentioned in references since the first half of the 20th century (SŁAWIŃSKI, 1924; SNARSKIS, 1954;
LeKAVIČIUS, 1963, 1989); however, later studies have revealed that all specimens previously identified as this species belong to E. quinqueflora (GUDŽINSKAS, 1999; TABAKA et al., 2003). Nevertheless, the occurrence of E. ovata in Lithuania has been predicted because of its current or past presence in the neighbouring territories (ABRoMEIT et al., 1940; ZAJĄC \& Zając, 2001; TABAKa et al., 2003; DedKov et al., 2010; Priedītis, 2014; KaźmiercZaKowa, 2016; SKuRATOVICH, 2017; KuUK, 2020). Thus, our discovery of this species in Lithuania was anticipated, and the record fulfils the gap in the distribution range of this species. Though finding this species in other localities is possible, its absence on the shores of other surveyed lakes in South Lithuania supports our presumption that it is indeed exceedingly rare. It should be noted that in the 1990s, plant communities of periodically inundated habitats had been studied in various regions of Lithuania; however, E. ovata was not recorded (Rašomavičius \& Biveinis, 1996).

Although the range of $E$. ovata is almost circumboreal, it is unevenly distributed in Europe, and in the Baltic Sea region is exceedingly rare (JIMÉNEZMejías \& Luceño, 2011; Simons et al., 2020). In Belarus, E. ovata has been considered a rare native species in the southern part of the country. In contrast, in the northern regions, it has been treated as a casual alien basing on the temporal character of populations (Skuratovich, 2017). However, the temporality of populations of E. ovata and other annual plant is a well-known phenomenon (KIRÁLY et al., 2008; Verloove, 2015; Simons et al., 2020) and frequently depends on the habitat availability (MARCINIUK et al., 2020). Therefore, we suppose that this species is native throughout Belarus, as all over the Baltic region. Its transient occurrence in fast-changing habitats along shores of lakes and other bodies of water may form the impression of a casual alien species.

As was already mentioned above, some specimens of E. quinqueflora are sometimes identified as E. ovata in Lithuania (TABAKA et al., 2003). However, these species can be easily distinguished, first, by the growth type. Eleocharis ovata is an annual plant, forms densely tufted culms and never produces rhizomes (Fig. 1), whereas E. quiqueflora is a perennial plant with well-developed rhizomes. Nevertheless, the identification of E. ovata should always be carefully verified, as several related alien species have 
been noted spreading in Europe. In the Netherlands and Belgium, the spread of E. engelmannii Steud. and E. obtusa (Willd.) Schult. (Verloove, 2015; SIMONS et al., 2020) have been noted. The three species are annuals with a caespitose habit, and they can be separated by the characters of achenes and, particularly, stylopodium. Stylopodium of E. ovata usually is about two-thirds as wide as achene, whereas E. engelmannii and E. obtusa is about as wide as achene. Furthermore, perianth bristles of E. engelmannii usually are equal to the length of achene and stylopodium, whereas in E. ovata and E. obtusa, perianth bristles are more extended than achene and stylopodium. Plants recorded in Lithuania according to all morphological characters without doubts belong to E. ovata.

Lake Pabezninkai is at the southern edge of the Dzūkai upland, a part of the Baltic Uplands (BASALYKAS, 2014). It is a shallow lake of glacial origin and occupies $61.4 \mathrm{ha}$, and is characterised by significant periodical fluctuations of the water level. At the peak of water level drop by $1.5-1.6 \mathrm{~m}$, the area of the lake shrinks to 38.2 ha, exposing sandy or muddy flats 30-100 m wide (GUDžInSKAS \& TAURA, 2021). The largest part of ca. 24 ha of exposed shores of the lake (ca. $13 \mathrm{ha}$ ) were covered by communities of annual plants. Dense stands of sedges and reeds occupied ca. $30 \%$ of the exposed area, and bare sand and mud comprised ca. $25 \%$ of the exposed area. Thus, there were large areas of habitats suitable for growing E. ovata. However, the total number of registered individuals as well as their density were relatively low.

Assessing the low density of E. ovata on the shores of Lake Pabezninkai, we suspect frequent self-pollination of flowers and, therefore, reduced seed viability. Our assumption is also indirectly supported by the fact that despite the observed high seed production, the abundance of individuals on the shores of the lake was low. Flowers of Eleocharis, as well as of most species of the Cyperaceae family, are wind-pollinated (WragG \& Johnson, 2011; Demeda et al., 2018). Studies on E. laeviglumis R. Trevis et Boldrini have revealed that the low germinability and vigour of seeds is plausibly caused by frequent geitonogamy (DEMEDA et al., 2018).

In perennial species of the genus Eleocharis, a low germinability of seeds produced after selfpollination is compensated by an intense spread by rhizomes, and it warrants population stability. However, frequent self-pollination in annual species may be an important limiting factor of their population viability (GROOM, 1998). Indeed, the effect of other factors on viable seed availability such as seed allocation in deeper substrate layers, seed predation, water-induced seed dispersal over a large area, and the time intervals between periods of low water level (Peterson \& Baldwin, 2004) cannot be excluded. However, the exact effect of each factor on the dynamics of $E$. ovata population should be assessed through broader research.

Eleocharis ovata is a diagnostic species of the Isoëto-Nanojuncetea Br.-Bl. et Tüxen ex Br.-Bl. et al. 1952 class and the Eleocharition ovatae Philippi 1968 (= Nanocyperion flavescentis Koch 1926) alliance (Šumberová, 2011). Occasionally this species occurs in other plant communities on the shores of different bodies of water (Hroudoví et al., 2011). It should be noted that several other annual species with similar ecological requirements (Cyperus fuscus L., Elatine hydropiper L., Isolepis setacea (L.) R.Br., Laphangium luteo-album (L.) Tzvelev) and characteristic of the Isoëto-Nanojuncetea class (Š́umBerovÁ, 2011), are considered as extinct, extremely rare or have not been found in Lithuania for several decades (RAšomavičIUS, 2007, 2021). We suppose that the size of E. ovata population could be unstable and depend on the water level fluctuation in Lake Pabezninkai and behave similarly to other species characteristic of transient plant communities developing on wet, muddy and sandy shores (MARCINIUK et al., 2020; GUDŽINSKAS \& TAURA, 2021).

Even though E. ovata has been found only recently in Lithuania; in our opinion, following the recommendations presented in the IUCN Guidelines (IUCN, 2012), this taxon is eligible for an assessment at the regional level. Information about threats to the species in other European countries supports our decision to evaluate $E$. ovata according to IUCN criteria in Lithuania. Eleocharis ovata is considered a species of least concern (BILz et al., 2011), but in several countries, it has been evaluated as a threatened species. In Luxembourg, it is localised within a restricted geographical area and occupies specific habitats; thus, applying the national categorisation is considered an extremely rare species (Colling, 2005). In the Netherlands and Hungary, it has been evalu- 
ated as near threatened (NT) species (KIRÁLY, 2007; SimONS et al., 2020) and critically endangered (CR) in Belgium (Verloove, 2015). In Poland, E. ovata has been evaluated as a vulnerable (VU) species both at the national and regional levels (JACKOWIAK et al., 2007; KAźMIERCZAKOwA et al., 2016). This species has received the same threat status in Slovakia (TuRIS et al., 2014).

Although we assessed E. ovata as a critically endangered species, we do not propose its inclusion in the list of legally protected species of Lithuania, because the measures for conservation of annual plants are pretty complicated. Suppose the low water level period lasts for a few years, and there is no periodic fluctuation. In that case, habitats may change due to succession and conditions suitable for annual plants may no longer exist. If the period of low water level lasts for several years and there is no significant periodic fluctuation, habitats may change due to their overgrowth with tall helophytes and shrubs and conditions suitable for annual plants may no longer exist. Nevertheless, conservation of E. ovata and other rare plant species recorded on the shores of Lake Pabezninkai should be organised by maintaining favourable habitat conditions applying feasible and possible measures.

\section{REFERENCES}

Abromeit J., Jentzsch A., Neuhoff W., Steffen H., Vogel G., 1940: Flora von Ost- und Westpreussen, 4. - Königsberg.

BASALYKAS A., 2014: Lietuvos kraštovaizdis. - Vilnius.

Bilz M., Kell S.P., Maxted N., Lansdown R.V., 2011: European Red List of Vascular Plants. Luxembourg.

Colling G., 2005: Red List of the vascular plants of Luxembourg. - Ferratia, 42: 1-77.

Dedkov V.P., Grishanov G.V., Gubareva I.J., 2010: Red Data Book of the Kaliningrad Region. - Kaliningrad.

Demeda C.L.B., Seger G.D.S., Steiner N., Trevisan R., 2018: Reproductive phenology and germination of Eleocharis laeviglumis R. Trevis. \& Boldrini (Cyperaceae). Acta Botanica Brasilica, 32(3): 487-492. http://dx.doi.org/10.1590/0102-33062018abb0200.
Di Marco M., Santini L., 2015: Human pressures predict species' geographic range size better than biological traits. - Global Change Biology, 21(6): 2169-2178. https://doi.org/10.1111/gcb.12834

FunK V.A., 2006: Floras: a model for biodiversity studies or a thing of the past? - Taxon, 55(3): 581-588.

Galen Smith S., Bruhl J.J., Socorro GonzálezElizondo M., Menapace F.J., 2002: Eleocharis R. Brown. - In: Flora of North America, 23: 60-120. - Oxford.

González-Elizondo M.S., Peterson P.M., 1997: A classification of and key to the supraspecific taxa in Eleocharis. - Taxon, 46: 433-449.

Govaerts R., Simpson D.A., Bruhl J.J., Egorova T., Goetghebeur P., Wilson K.L., 2007: World Checklist of Cyperaceae. - Kew.

Groom M.J., 1998: Allee effects limit population viability of an annual plant. - The American Naturalist, 151(6): 487-496.

GuDŽINSKAS Z., 1999: Lietuvos induočiai augalai. Vascular Plants of Lithuania. - Vilnius.

GudžInSKas Z., TAuRA L., 2021: Scirpus radicans (Cyperaceae), a newly-discovered native species in Lithuania: population, habitats and threats. - Biodiversity Data Journal, 9: e65674. https://doi.org/10.3897/BDJ.9.e65674.

Hroudová Z., Ekrt L., Ekrtová E., Šumberová K., 2011: MCC05 Scirpetum radicantis Nowiński 1930. Mokřadní vegetace se skř́ípinou kořenující. - In: ChYtrÝ M. (ed.), Vegetation of the Czech Republic. 3. Aquatic and wetland vegetation: 462-465. - Praha.

IUCN, 2012: Guidelines for Application of IUCN Red List Criteria at Regional and National Levels. Version 4.0. - Gland-Cambridge.

IUCN, 2017: Guidelines for Using the IUCN Red List Categories and Criteria. Version 14. -GlandCambridge.

Jackowiak B., Celka Z., Chmiel J., Latowski K., ŻUKOwsKI W., 2007: Red list of vascular flora of Wielkopolska (Poland). - Biodiversity: Research and Conservation, 5-8: 95-127.

JimÉnez-Mejías P., Luceño M., 2011: Cyperaceae. Euro+Med Plantbase. The information resource for Euro-Mediterranean plant diversity. http://ww2.bgbm.org/EuroPlusMed/query.asp [accessed 16 March 2021]. 
KAŹmierczaKowa R. (ed.), 2016: Polish Red List of Pteridophytes and Flowering Plants. - Kraków.

KIRÁly G. (ed.), 2007: Vörös Lista. A magyarországi edényes flóra veszélyeztetett fajai. Red list of the vascular flora of Hungary. - Sopron.

Király G., Mesterházy A., Király A., Pinke G., PÁL R., 2008: Auftreten von Nanocyperion-Arten in Westungarn - die Rolle der Feuchtäcker in ihrer Erhaltung. - Journal of Plant Diseases and Protection, Special Issue, 21: 413-418.

KuUK T., 1999: Eesti taimestik. - Tartu-Tallinn.

KuUK T., 2020: Eesti taimede levikuatlas. Atlas of the Estonian Flora. https://ottluuk.github.io/atlas/contact.html [accessed 4 April 2021].

Kuusk V., Tabaka L., Jankevičiené R. (eds), 2003: Flora of the Baltic Countries, 3. - Tartu.

LEKAVIČIIUS A., 1963: CYPERACEAE J. St. Hill. subfam. Scirpoideae Pax. - In: NATKEviČAité-IVANAUSKIENĖ M. (ed.), Lietuvos TSR flora, 2: 302-335. - Vilnius.

LeKAVIČıUs A., 1989: Vadovas augalams pažinti. Vilnius.

LiNDER H.P., 2005: Evolution of diversity: The Cape flora. - Trends in Plant Science, 10(11): 536-541. https://doi.org/10.1016/j.tplants.2005.09.006.

Marciniuk P.L., Marciniuk J., Łysko A., KraJewski Ł., Chudecka J., Skrzyczyńska J., PopIELA A.A., 2020: Rediscovery of Cyperus flavescens (Cyperaceae) on the northeast periphery of its range in Europe. - PeerJ, 8: e9837. http://doi.org/10.7717/peerj.9837.

Matulevičiūtė D., 2001: Carex depressa subsp. transilvanica and C. tomentosa in Lithuania. Botanica Lithuanica, 7(3): 303-306.

Matulevičiūté D., 2003: Carex juncella in Lithuania: distribution, state, and communities. - Botanica Lithuanica, 9(4): 315-328.

Peterson J.E., Baldwin A.H., 2004: Variation in wetland seed banks across a tidal freshwater landscape. - American Journal of Botany, 91(8): 1251-1259.

Priedītis N., 2014: Latvijas augi. Plants of Latvia. Rīga.

RAšomaviČıus V. (ed.), 2007: Lietuvos raudonoji knyga. - Vilnius.
RAŠOMAVIČIUS V. (ed.), 2021: Lietuvos raudonoji knyga. Gyvūnai. Augalai. Grybai. Red Data Book of Lithuania. Animals. Plants. Fungi. - Vilnius.

Rašomavičius V., Biveinis A., 1996: The communities of the Isoeto-Nanojuncetea bufonii Br.-Bl. et R. Tx. 1943 class in Lithuania. - Botanica Lithuanica, 2(1): 3-25.

Simons E.L.A.N., Wieringa J.J., GongGriJP S., 2020: Eleocharis ovata and its alien allies in the Netherlands. - Gorteria. Dutch Botanical Archives, 42: 028-035.

Skuratovich A.N., 2017: Cyperaceae Juss. - In: Flora Belarusi. Sosudistye rastenija, 3: 351-543. Minsk.

SŁaWIŃsKi W., 1924: Zielone jeziora pod Wilnem. Wilno.

SNARSKIS P., 1954: Vadovas Lietuvos TSR augalams pažinti. - Vilnius.

StanceviČIUs A., 1963: Cyperaceae J. St. Hill. subfam. Caricoideae Pax. - In: NATKevičAitèIvanauskienĖ M. (ed.), Lietuvos TSR flora, 2: 343-452. - Vilnius.

Šumberová K., 2011: Isoëto-Nano-Juncetea. Vegetation of annual wetland herbs. - In: CHYTRÝ M. (ed.), Vegetation of the Czec Republic. 3. Aquatic and Wetland Vegetation: 309-346. - Praha.

Tabaka L., Krall H., Rašomavičius V., 2003: Eleocharis R. Brown. - In: KuUsK V., TABAKA L., JANKEVIČIENĖ R. (eds), Flora of the Baltic Countries, 3: 331-333. - Tartu.

Turis P., Kliment J., Feráková K., Dítě D., Eliaš P., Hrivnák R., Koštal J., Šuvada R., Mraz P., BERNÁTOVÁ D., 2014: Red List of vascular plants of the Carpathian part of Slovakia. - Thaiszia Journal of Botany, 24 (1): 35-87.

Verloove F., 2015: Eleocharis engelmannii and E. obtusa in Belgium. - Dumortiera, 107: 25-30.

WragG P.D., Johnson S.D., 2011: Transition from wind pollination to insect pollination in sedges: experimental evidence and functional traits. - New Phytologist, 191(4): 1128-1140. doi:10.1111/j.1469-8137.2011.03762.x.

ZająC A., ZająC M. (eds), 2001: Atlas rozmieszczenia roślin naczyniowych w Polsce. Distribution Atlas of Vascular Plants in Poland. - Kraków. 


\section{PATVIRTINTA, KAD SAVAIMINĖ AUGALŲ RŪŠIS ELEOCHARIS OVATA (CYPERACEAE) RASTA LIETUVOJE}

\section{Zigmantas GUDŽINSKAS, Laurynas TAURA}

\section{Santrauka}

Krantinis duonis (Eleocharis ovata) XX a. buvo ne kartą minètas literatūros šaltiniuose, tačiau vèliau paaiškejjo, kad visi herbariumo pavyzdžiai buvo apibūdinti klaidingai. Nepaisant to, buvo tikimasi, jog šios rūšies augalai gali būti aptikti šalyje, nes jie anksčiau augo arba iki šiol auga visuose gretimuose regionuose. Daugelyje Vidurio ir Rytų Europos šalių E. ovata yra reta ir nykstanti rūšis. Latvijoje ir Kaliningrado srityje augalas dabar neaptinkamas, o Estijoje po daugiau kaip 100 metų pertraukos vèl surastas $2012 \mathrm{~m}$.

Vykdant tyrimus Pietų Lietuvoje, $2020 \mathrm{~m}$. E. ovata populiacija buvo surasta Varėnos rajone, Pabezninkų ežero pakrantèje. Lauko tyrimų, kurie buvo vykdyti $2020 \mathrm{~m}$. rugpjūčio-spalio mèn. metu, ištirtas E. ovata individu paplitimas, ịvertintas populiacijos dydis ir užimamos buveinès Pabezninkų ežero pakrantèse. Taip pat buvo vykdoma šios rūšies augalų paieška aštuoniuose Pietų Lietuvos ežeruose, bet kitų ežerų pakrantėse jų nebuvo aptikta. Ivvertinus nuslūgusio Pabezninkų ežero drègnas smèlètas ir dumblingas pakrantes, iš viso buvo aptikti 63 plačiai pasklidę, atokiai vienas nuo kito augantys $E$. ovata individai. Dauguma aptiktų E. ovata augalų augo drègname smèlyje arba dumble įsikūrusiose IsoëtoNanojuncetea klasès bendrijose. Pavienių individu buvo rasta Phragmito-Magnocaricetea klasès bendrijose.

Apibendrinus tyrimu duomenis ir ivertinus vienintelę Lietuvoje žinomą E. ovata populiaciją pagal IUCN kriterijus, nustatyta, kad šis augalas turi būti priskirtas prie kritiškai grèsmingos būklès (CR) rūšių grupès. Norint išsaugoti E. ovata ir kitų, Pabezninkų ežero pakrantèse augančių saugomų rūšiu populiacijas, būtina imtis priemonių, kad būtu užtikrinta ir nuolat palaikoma palanki seklių ežerų buveinių apsaugos būklè. Lietuvoje dabar patvirtintos šešios duonio (Eleocharis R. Br.) genties rūšys: adatinis duonis (E. acicularis (L.) Roem. et Schult.), karpuotasis duonis (E. mamillata (H.Lindb.) H.Lindb.), krantinis duonis (E. ovata (Roth) Roem. et Schult.), pelkinis duonis (E. palustris (L.) R.Br.), ganyklinis duonis (E. quinqueflora (Hartmann) O. Schwarz) ir pievinis duonis (E. uniglumis (Link) Schult.). 